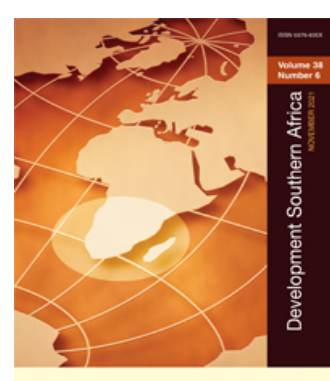

\title{
Revisiting the COVID-19 vulnerability index in South Africa
}

\section{Derek Yu}

To cite this article: Derek Yu (2021): Revisiting the COVID-19 vulnerability index in South Africa, Development Southern Africa, DOI: 10.1080/0376835X.2021.1973887

To link to this article: https://doi.org/10.1080/0376835X.2021.1973887

册 Published online: 13 Sep 2021.

Submit your article to this journal

III Article views: 364

Q View related articles $\longleftarrow$

View Crossmark data \lceil 


\section{Revisiting the COVID-19 vulnerability index in South Africa}

\section{Derek Yu}

Professor, Department of Economics, University of the Western Cape, Bellville, South Africa

\begin{abstract}
This study uses the Census 2011 and Community Survey 2016 data, adopts the Alkire-Foster multidimensional poverty index (MPI) approach and addresses numerous shortcomings of the original Statistics South Africa method by including numerous indicators from four dimensions (socio-economic, demographic, housing and hygiene, health) to derive a revised COVID-19 vulnerability index. The empirical findings indicate the index was relatively higher for African female individuals living in rural areas of the Eastern Cape, KwaZulu-Natal and Limpopo provinces, coming from households headed by elderly aged 55 years or above. Alfred Nzo, Amathole, Harry Gwala, OR Tambo and Umzinyathi are the five district councils that are most vulnerable to COVID-19 (the first four were declared COVID-19 hotspot areas by the South African government in December 2020). The results of the index decomposition found that indicators from the housing and hygiene dimension contributed most to the COVID-19 vulnerability.
\end{abstract}

\section{KEYWORDS}

COVID-19 vulnerability index; multidimensional poverty; South Africa

JEL

$\mathrm{J} 30 ; \mathrm{J} 32$

\section{Introduction}

The coronavirus (COVID-19), an infectious disease caused by severe acute respiratory syndrome coronavirus 2 (or SARS-CoV-2), has been spreading fast across the world since November 2019, and was declared a global pandemic by the World Health Organisation on 11 March 2020. In South Africa, the first case of COVID-19 was detected on 1 March, before President Cyril Ramaphosa declared on 15 March that COVID-19 was a national disaster. The country underwent lockdown level 5 on 27 March for five weeks, before dropping to level 4 and level 3 on 1 May and 1 June, respectively. The lockdown level dropped further to level 2 on 17 August and level 1 on 21 September, as the country was open again to inter-provincial and international travel, and more sectors were allowed to operate their businesses under strict health protocols (Republic of South Africa, 2021).

Unfortunately, with the advent of the second wave and identification of the new variant in early December, it was announced that three district councils (DCs) became hotspot areas with stricter lockdown rules, namely Garden Route District, Nelson Mandela Bay Metro and Sarah Baartman District. An additional 23 DCs were included as hotspot areas when Ramaphosa announced the country moved to an adjusted 
lockdown level 3 on 29 December (South African Government, 2020). On 28 February 2021 , it was announced that the country would move from level 3 to adjusted level 1. Furthermore, due to surge in infections or the start of the third wave since early May, restrictions were tightened again and the country moved from adjusted lockdown level 1-2 on 31 May 2021.

At the time of writing, more than 170 million people were infected with the virus across the globe, with 3.6 million deaths in total. In South Africa, nearly 1.7 million people were infected, with more than 1.5 million people recovering from the illness but close to 57000 people passed away (that is, recovery rate is $93.5 \%$ while death rate is $3.4 \%$ ), and there still remains about 50000 active cases (Republic of South Africa, 2021). It was also announced by the Health Minister Zweli Mkhize that a three-phase distribution process is adopted to roll out the COVID-19 vaccine, with the primary aim of having 40 million (or two-thirds of the national population) to be immunised by the end of February 2022 to achieve herd immunity in order to break the cycle of transmission (Republic of South Africa, 2021).

While South Africans await their turns to receive the vaccines (only one million people were vaccinated at the time of this study), in the meantime, it is important to identify the people and areas most vulnerable to the pandemic to reduce transmission. During 2020, a handful of international studies were conducted to derive a COVID-19 vulnerability index to distinguish these people and areas. Statistics South Africa (StatsSA) also published a report in mid-December 2020 by adopting the Alkire-Foster multidimensional poverty (MPI) approach to derive this index by taking eight indicators from four dimensions into consideration (it will be discussed in greater detail in the next section).

This study aims to develop an improved, revised version of the COVID-19 vulnerability index, before adopting the revised MPI approach to analyse the Census 2011 and Community Survey 2016 data to investigate the areas as well characteristics of people most vulnerable to the pandemic, by considering a wider range of indicators from four dimensions. The empirical analysis also allows for identification of the main indicators or risk factors which contribute most to the pandemic vulnerability by means of conducting index decomposition. It is hoped that the findings and suggestions of this study would help the government in its policy and rules to quicker identify the atrisk people and areas and reduce transmission.

\section{Literature review}

Poverty is not only about low income and expenditure, but involves numerous nonmoney-metric dimensions such as health and educational deprivation, lack of asset possession, insufficient access to services, physical and social isolation, as well as feeling helpless, powerless and vulnerable (Woolard \& Leibbrandt, 1999; World Bank, 2000; Philip \& Rayhan, 2004). Hence, methods such Factor Analysis, Multiple Correspondence Analysis, Principal Components Analysis and the Total Fuzzy Sets approach have been commonly adopted over the years to derive a non-money-metric multidimensional index to examine poverty in South Africa, along with the conventional money-metric approach (which looks at per capita income or expenditure). The MPI method is a relatively new approach in South Africa to examine multidimensional poverty, and at the time of writing, there are numerous local studies using this approach for multidimensional 
poverty analysis, such as Finn et al. (2013), StatsSA (2014), Frame et al. (2017), Mushongera et al. (2017), Omotoso and Koch (2017), Rogan (2016), Fransman and Yu (2019). ${ }^{1}$

At the time of writing, StatsSA (2020) is the only local study that adopted the MPI approach to derive the COVID-19 vulnerability index. In this study, eight indicators (employment status and car ownership, media access, water access, sanitation source, overcrowding, multigenerational households, presence of elderly household members and receipt of chronic medication) from four dimensions (population dynamics, household service dynamics, household status dynamics and health) were considered before the index was derived to compare the results by DC and municipality. Note that the report did not provide these results in detail, but rather referred the readers to an online dashboard site. ${ }^{2}$

To the author's knowledge, four international studies were released at the time of writing on derivation of the COVID-19 vulnerability index. First, Acharya and Porwal (2020) considered 15 indicators from five dimensions (socio-economic, demographic, housing and hygiene, epidemiological and health system) to derive a composite vulnerability index at state and district levels in India. The empirical findings indicated that numerous districts in nine large states (Bihar, Gujarat, Jharkhand, Madhya Pradesh, Maharashtra, Odisha, Telangana, Utter Pradesh and West Bengal) were associated with high overall vulnerability with the index exceeding 0.75 . Next, the study by Decaprio et al. (2020) considered four risk factors (older adults, individuals with heart disease, people with diabetes and people with lung disease) to derive the vulnerability index in the USA to identify individuals with pre-existing medical conditions who were at the greatest risk for severe COVID-19-related complications.

Looking at the other studies, Macharia et al. (2020) included 24 indicators from four dimensions (socio-economic deprivation, population characteristics, access to services and epidemiological background) to derive the COVID-19 vulnerability index in Kenya, and found that 46 sub-counties (which represented 7.0 million people) located around central and south eastern were more vulnerable to the pandemic, whilst 81 sub-counties (14.4 million individuals) were least vulnerable to it. Lastly, Nair (2020) considered 12 indicators from the socio-economic, demographic, transportation and health dimensions to derive the vulnerability index to identify counties that are vulnerable to the pandemic in the USA, with the aid of the Principal Components Analysis statistical technique. The empirical findings suggested that counties with high vulnerability index were associated with high COVID-19 case rates.

\section{Methodology and data}

\subsection{Methodology}

The original global MPI approach was introduced in 2011 by Alkire and Foster for the purpose of measuring acute multidimensional poverty across countries. This approach comprises 10 indicators from three dimensions, namely health, education and living standard (Santos and Alkire, 2011:5-6). A two-step approach is adopted to derive the MPI index (Alkire and Foster, 2011: 296). First, linked to each indicator is a minimum

\footnotetext{
${ }^{1}$ These literatures are not reviewed in detail here, given this study primarily relates to COVID-19 vulnerability.

${ }^{2}$ Link to this online dashboard: http://www.statssa.gov.za/?p=13875
} 
level of satisfaction, namely the deprivation cut-off point $\left(z_{i}\right)$. An individual or household $i$ is deprived in this indicator if his/her achievement in this indicator, $x_{i}$, is below the cutoff (i.e. $x_{i}<z_{i}$ ) and hence the dummy variable $I_{i}$ equals one. Conversely, $I_{i}$ equals zero if $x_{i} \geq z_{i}$. The indicators' weights are then chosen, and these weights sum to $1\left(\sum_{i=1}^{m} w_{i}=1\right)$. Each dimension carries the same weight of one-third, and an equal weighing scheme is applied to the indicators within each dimension. The deprivation score, $c_{i}$, is calculated as: $\sum_{i=1}^{m} w_{i} I_{i}$, with this score ranging from zero to one.

A specific cut-off point, $k$, stands for the share of weighted deprivations a person must have before he/she is regarded as multidimensionally poor. Someone is distinguished as poor if $c_{i} \geq k$. In the MPI, $k=1 / 3$, meaning the person's deprivation must be at least a third of the weighted indicators to be distinguished as MPI poor. In addition, $c_{i}(k)$, the censored deprivation score, is derived as follows: if $c_{i} \geq k, c_{i}(k)=c_{i}$; if $c_{i}<k, c_{i}(k)=$ 0 (Santos and Alkire, 2011:11).

The MPI reflects both the percentage of population that is multidimensionally poor $(H$ or the poverty headcount ratio) and average proportion of weighted deprivation the person experiences ( $A$ or the intensity of poverty). In equation terms, $H=q / n$, where $q$ and $n$ denote the number of multidimensionally poor and total population respectively. Moreover, $A=\frac{\sum_{i=1}^{n} c_{i}(k)}{q}$, which represents the fraction of the $m$ indicators in which the multidimensionally poor individual is deprived. The MPI is calculated as $H \times A$. Lastly, the MPI index can be decomposed by population sub-groups or indicators, in order to find out the demographic characteristics of people as well as indicators that contribute most to the MPI (refer to Santos and Alkire (2011) as well as Fransman and Yu (2019) for detailed mathematical explanation).

This study adopts the MPI approach by revising the indicators, dimensions and cut-off points from the StatsSA 2020 study to re-derive the COVID-19 vulnerability index, as shown in Tables 1 and 2, with the last column of both tables indicating the weight of

Table 1. Dimensions, indicators, deprivation cut-offs and weights for the COVID-19 vulnerability index, Census 2011.

\begin{tabular}{|c|c|c|c|}
\hline Dimension & Indicator & Deprivation cut-off & Weight \\
\hline \multirow[t]{4}{*}{ Socio-economic } & {$[\mathrm{A}]$ : Education } & $\begin{array}{l}\text { None of working-age household member completed } \\
\text { Matric }\end{array}$ & $1 / 16$ \\
\hline & [B]: Informal employment & At least one member working in the informal sector & $1 / 16$ \\
\hline & [C]: Car ownership & Did not own a motor vehicle & $1 / 16$ \\
\hline & [D]: Access to media & $\begin{array}{l}\text { Did not own any one of television, radio, cellphone and } \\
\text { has no access to internet }\end{array}$ & $1 / 16$ \\
\hline \multirow[t]{2}{*}{ Demographic } & $\begin{array}{l}\text { [E]: Multigenerational } \\
\text { households }\end{array}$ & $\begin{array}{l}\text { Children ( } 0-15 \text { years) and elderly }(60+) \text { both present in } \\
\text { the household }\end{array}$ & $1 / 8$ \\
\hline & [F]: Overcrowding & More than two people per functional room & $1 / 8$ \\
\hline \multirow{4}{*}{$\begin{array}{l}\text { Housing and } \\
\text { hygiene }\end{array}$} & [G]: Dwelling type & Informal dwelling & $1 / 16$ \\
\hline & {$[\mathrm{H}]$ : Refuse removal } & Not removed by local authorities at least once a week & $1 / 16$ \\
\hline & [l]: Water & Did not have access to water within $200 \mathrm{~m}$ of the dwelling & $1 / 16$ \\
\hline & [J]: Sanitation & Did not have own flush/chemical toilet in dwelling & $1 / 16$ \\
\hline \multirow[t]{2}{*}{ Health } & [K]: Disability & At least one member with disability problem & $1 / 8$ \\
\hline & [L]: Chronic medication & At least one member using chronic medication & $1 / 8$ \\
\hline
\end{tabular}

Source: Adapted from Statistics South Africa, 2020. 
Table 2. Dimensions, indicators, deprivation cut-offs and weights for the COVID-19 vulnerability index, Community Survey 2016.

\begin{tabular}{|c|c|c|c|}
\hline Dimension & Indicator & Deprivation cut-off & Weight \\
\hline \multirow[t]{3}{*}{ Socio-economic } & [I]: Education & $\begin{array}{l}\text { None of working-age household member completed } \\
\text { Matric }\end{array}$ & $1 / 12$ \\
\hline & [II]: Car ownership & Did not own a motor vehicle & $1 / 12$ \\
\hline & [III]: Access to media & $\begin{array}{l}\text { Did not own any one of television, radio, cellphone and } \\
\text { has no access to internet }\end{array}$ & $1 / 12$ \\
\hline \multirow[t]{2}{*}{ Demographic } & $\begin{array}{l}\text { [IV]: Multigenerational } \\
\text { households }\end{array}$ & $\begin{array}{l}\text { Children (0-15 years) and elderly }(60+) \text { both present in } \\
\text { the household }\end{array}$ & $1 / 8$ \\
\hline & [V]: Overcrowding & More than six people in the household & $1 / 8$ \\
\hline \multirow{4}{*}{$\begin{array}{l}\text { Housing and } \\
\text { hygiene }\end{array}$} & [VI]: Dwelling type & Informal dwelling & $1 / 16$ \\
\hline & [VII]: Refuse removal & Not removed by local authorities at least once a week & $1 / 16$ \\
\hline & [VIII]: Water & Did not have access to water within $200 \mathrm{~m}$ of the dwelling & $1 / 16$ \\
\hline & [IX]: Sanitation & Did not have own flush/chemical toilet in dwelling & $1 / 16$ \\
\hline \multirow[t]{3}{*}{ Health } & [X]: Disability & At least one member with disability problem & $1 / 12$ \\
\hline & [XI]: Malnutrition & $\begin{array}{l}\text { Ran out of money to buy food or skipped a meal }+5 \text { days } \\
\text { in past } 30 \text { days }\end{array}$ & $1 / 12$ \\
\hline & [XII]: Public healthcare & $\begin{array}{l}\text { Poor quality or no access to public clinic and public } \\
\text { hospital }\end{array}$ & $1 / 12$ \\
\hline
\end{tabular}

Source: Adapted from Statistics South Africa, 2020.

each indicator. Note that the indicators are not exactly the same in Census 2011 and Community Survey (CS) 2016, as the questionnaire design was not identical in the two years.

The indicators come from four dimensions (socio-economic, demographic, housing and hygiene, and health), as vulnerable individuals should not be confined to elderly and those with comorbidities and ill health, but also those from certain socio-economic groups who struggle to cope with the pandemic financially, mentally and physically (The Lancet 2020).

With regard to the indicators in the first dimension (socio-economic), educational attainment was not included from the StatsSA approach but is included in this study, as it is an important indicator to reflect the socio-economic conditions of the households. Note that this indicator was also included in the 2020 Acharya and Porwal as well as Macharia et al. studies. Whilst the StatsSA approach included the 'at least one employed household member and the household does not own a motor vehicle' indicator, this study rather treats the two variables separately. In 2011, two different indicators are included, namely 'at least one member working in the informal sector' and 'the household does not own a motor vehicle'. It is important to separate the two variables (this approach was also adopted in the 2020 Macharia et al. study), because household members who rely on public transport for purposes other than work (e.g. shopping for groceries) can also be vulnerable to the pandemic. One drawback is that StatsSA did not release data in connection with the whole labour market section in CS 2016, and thus it is not possible to include the informal sector indicator in 2016. Lastly, the media access indicator is derived in the same way as the StatsSA 2020 study.

Moving on to the second dimension (demographic), the multigenerational household variable is derived in the same way as StatsSA (2020) did. With regard to the overcrowding indicator, in this study, in Census 2011, the cut-off point is rather changed from 'more than three people per functional room' (the StatsSA approach) to 'more than two people per function room', because it is extremely difficult for self-isolation and 
$1.5 \mathrm{~m}$ social distancing to be feasible if there are three people in the same room. In CS 2016, it is unfortunate that the number of rooms question was not asked. However, given the mean number of rooms was about four (4.10) in Census 2011, and it is assumed that we can accommodate two people in the main bedroom for household head and his/her spouse, another two people (e.g. children) in the second bedroom, one person in the living room and one person in the dining room (that is, six people in total for four functional rooms), it is decided to adopt the 'more than six people in the dwelling' cut-off point for the overcrowding indicator in CS 2016.

As far as the housing and hygiene dimension is concerned, in this study, water and sanitation indicators are included and the same cut-offs are adopted as in the StatsSA 2020 study. However, this study includes two additional indicators, namely dwelling type (threshold: informal dwelling) and refuse removal (threshold: refuse is not removed at least once a week), as these two indicators are also important to reflect the housing and hygiene condition of the household. These two indicators were also included in some of the international studies reviewed earlier (Acharya \& Porwal, 2020; Macharia et al., 2020).

Finally, for the health dimension, in the 2020 StatsSA study, two indicators - chronic medication and presence of elderly household members - were included. In this study, in Census 2011, the chronic medication indicator is still included (unfortunately the information was no longer captured in CS 2016), but the presence of elderly members indicator is not included. The two main reasons for the exclusion of the latter indicator is that the recent news clearly suggests the youth population are also likely to be infected with the virus upon the identification of the new variant (Kubheka, 2020), and there is a strong correlation between this indicator and the earlier discussed multigenerational households indicator (correlation coefficient between the two indicators is quite high at 0.67 ).

The disability indicator is included for both years in this study, as people who have a lot of difficulty to perform or cannot perform certain duties at all clearly need assistance from fellow household members, meaning it is relatively more difficult for the members to self-isolate or subsequently they are under greater risk to be transmitted with the virus. Lastly, malnutrition and access to public healthcare are included as additional healthrelated indicators in 2016 (unfortunately the information was not captured in Census 2011). Note that similar indicators were also included by Acharya and Porwal (2020) as well as Macharia et al. (2020) by rather omitted by StatsSA (2020).

The MPI method discussed at the start of this section is adopted to derive the COVID19 vulnerability index, before the index estimates are derived and compared by personal, geographical and income characteristics in 2011 and 2016. The index decomposition by these characteristics as well as indicators is also conducted.

\subsection{Data}

Two StatsSA data sets are used: the original 10\% sample of Census 2001 and CS 2016 data that was released by StatsSA. These data sets provide comprehensive personal- and household-level information on demographic characteristics, educational attainment, labour market activities, asset ownership, access to household goods and services, as well as household income in interval terms. 
One serious drawback is the non-availability of 2016 CS data on labour market activities, even though the information was captured. In addition, as mentioned earlier, the questions on malnutrition and public healthcare access were not asked in Census 2011, whereas information on number of rooms in the dwelling and receipt of chronic medication was not captured in CS 2016. This explains the indicators included and why the weighting of each indicator are not exactly the same in both years. Therefore, the forthcoming empirical findings need to be interpreted with caution when it comes to comparison of results between the two years.

Another drawback is that StatsSA also did not release household income data in CS 2016. Whilst the information is released in Census 2011, more than 15\% of households declared either zero or unspecified income. Therefore, for these households, the sequential regression multivariable imputation (SRMI) approach is adopted to impute the income of these households. ${ }^{3}$ The household income variable after SRMI is used to derive the quintile variable (dividing the households into five groups, with an equal $20 \%$ share per quintile) which is used for the forthcoming empirical analysis.

\section{Empirical findings}

\subsection{Extent of deprivation per indicator}

Figure 1 illustrates that there was generally a continuous downward trend in the proportion of deprived population for the indicators that were captured in both years, with the exception of overcrowding as the proportion increased from $15.6 \%$ to $20.3 \%$. In both years, the proportion of deprived population was the greatest for the motor vehicle ownership indicator (nearly $70 \%$ ), followed by refuse removal (41\%) and education (approximately 40\%). The deprivation proportion was the lowest for the media access indicator (2011: 3.1\%; 2016: 1.8\%). The latter result is not anything surprising because cellular telephone ownership has become much more prevalent during the decade of the 2010 .

\subsection{Vulnerability index by sub-groups}

The COVID-19 vulnerability index estimates by numerous characteristics are shown in Table 3. For the overall population, the index hovered around the $0.14-0.15$ range, while the poverty headcount estimate was roughly $31 \%$ in both years. Table 3 also shows that individuals coming from households headed by elderly female Africans and residing in rural areas of the Eastern Cape, KwaZulu-Natal and Limpopo provinces were more vulnerable to the pandemic, as shown by the relatively higher vulnerability index. For the results by income quintile variable in 2011, as expected, higher income quintiles are associated with lower headcount ratio and lower vulnerability index.

Table A.1 shows what happened in all 52 DCs, whereas Table 4 shows the top 10 and bottom 10 DCs with the lowest and highest index estimates, respectively. Table 4 shows that, for the 10 DCs with the lowest index in 2011, eight of them remained in the top 10 in 2016 (Cape Winelands, City of Cape Town, City of Johannesburg, Ekurhuleni, Nelson

${ }^{3}$ Detailed mathematical explanation of the SRMI approach falls beyond the scope of this study, but the readers can refer to Raghunathan et al. (2001), Ardington et al. (2006), Lacerda et al. (2008) and Vermaak (2008). 


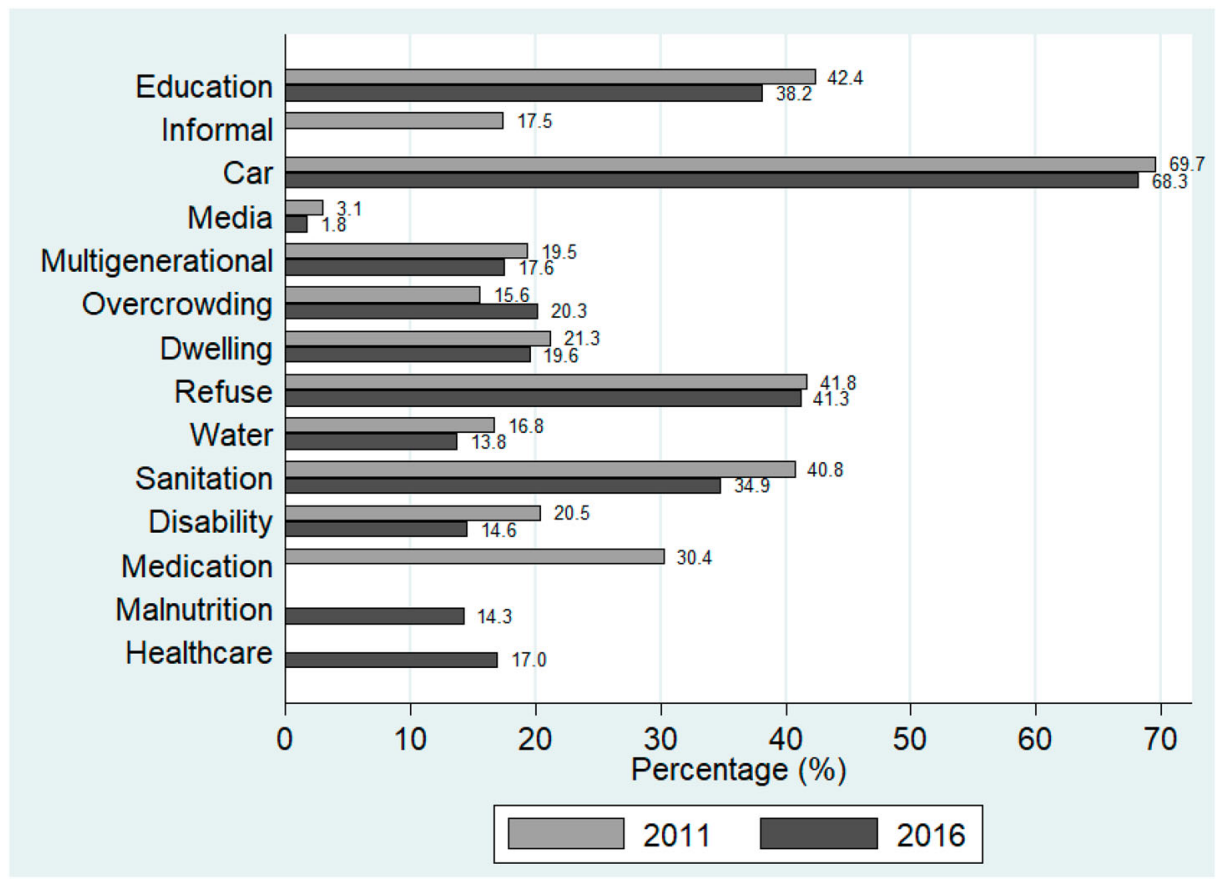

Figure 1. Proportion (\%) of population deprived in each indicator. Source: Authors' calculations using Census 2011 and Community Survey 2016 data.

Mandela Bay, Overberg, Sedibeng and West Rand). Moreover, for the bottom 10 DCs with the greatest index estimate in 2011, seven of them were also ranked in the bottom 10 in 2016 (Alfred Nzo, Amathole, Harry Gwala, OR Tambo, Ugu, Umkhanyakude and Umzinyathi). Furthermore, six out of the bottom 10 DCs in 2011 with the highest vulnerability index were declared as COVID-19 hotspot areas by Ramaphosa in December 2020, namely Alfred Nzo, Amathole, Chris Hani, Harry Gwala, OR Tambo and Ugu (Republic of South Africa, 2020).

The cut-off point of 0.25 was adopted in the StatsSA 2020 study to distinguish the COVID-19 vulnerable or 'poor' individuals. This study adopted the more universally adopted threshold of 0.33 as in the 2010 Alkire and Santos original approach, Table A.2 examines the vulnerability estimates and ranking of the DCs by using different thresholds $(0.25,0.33,0.40$ and 0.50$)$, and the results suggest that there are not any drastic changes in the ranking of DCs.

Lastly, Table A3 shows the 30 municipalities with the greatest COVID-19 vulnerability index in each year, and the results indicate that most of them are located in Eastern Cape and KwaZulu-Natal.

\subsection{Profile of the vulnerable people and index decomposition}

Table 5 shows that, as expected, individuals being vulnerable to the pandemic were predominantly those coming from households headed by females (about 55\%), Africans (95\%) and older adults aged at least 55 years (about 50\%), living in rural areas (two- 
Table 3. COVID-19 vulnerability index by demographic, geographical and income characteristics.

\begin{tabular}{|c|c|c|c|c|c|c|c|}
\hline & & \multicolumn{3}{|c|}{2011} & \multicolumn{3}{|c|}{2016} \\
\hline & & $\mathrm{H}$ & A & Index & $\mathrm{H}$ & A & Index \\
\hline All & All & 0.3105 & 0.4789 & 0.1487 & 0.3190 & 0.4484 & 0.1431 \\
\hline \multirow[t]{2}{*}{ Gender } & Male & 0.2508 & 0.4735 & 0.1188 & 0.2538 & 0.4405 & 0.1118 \\
\hline & Female & 0.3846 & 0.4833 & 0.1859 & 0.3966 & 0.4545 & 0.1803 \\
\hline \multirow[t]{4}{*}{ Race } & African & 0.3620 & 0.4817 & 0.1744 & 0.3688 & 0.4504 & 0.1661 \\
\hline & Coloured & 0.2095 & 0.4488 & 0.0940 & 0.1659 & 0.4145 & 0.0687 \\
\hline & Indian & 0.0549 & 0.4166 & 0.0229 & 0.0368 & 0.3848 & 0.0142 \\
\hline & White & 0.0258 & 0.4118 & 0.0106 & 0.0145 & 0.3847 & 0.0056 \\
\hline \multirow[t]{7}{*}{ Age } & $0-14$ years & 0.3014 & 0.4362 & 0.1314 & 0.4811 & 0.4316 & 0.2076 \\
\hline & $15-24$ years & 0.2030 & 0.4379 & 0.0889 & 0.3084 & 0.4217 & 0.1300 \\
\hline & $25-34$ years & 0.1926 & 0.4441 & 0.0855 & 0.2415 & 0.4190 & 0.1012 \\
\hline & $35-44$ years & 0.2130 & 0.4530 & 0.0965 & 0.2261 & 0.4238 & 0.0958 \\
\hline & $45-54$ years & 0.2586 & 0.4620 & 0.1195 & 0.2551 & 0.4312 & 0.1100 \\
\hline & $55-64$ years & 0.4038 & 0.4897 & 0.1977 & 0.3935 & 0.4582 & 0.1803 \\
\hline & $65+$ years & 0.5888 & 0.5125 & 0.3017 & 0.5713 & 0.4872 & 0.2783 \\
\hline \multirow[t]{2}{*}{ Area type } & Urban & 0.1612 & 0.4457 & 0.0719 & 0.1646 & 0.4126 & 0.0679 \\
\hline & Rural & 0.5622 & 0.4950 & 0.2783 & 0.6197 & 0.4670 & 0.2894 \\
\hline \multirow[t]{9}{*}{ Province } & Western Cape & 0.1596 & 0.4383 & 0.0700 & 0.1328 & 0.4035 & 0.0536 \\
\hline & Eastern Cape & 0.5188 & 0.5157 & 0.2675 & 0.5069 & 0.4802 & 0.2434 \\
\hline & Northern Cape & 0.3460 & 0.4764 & 0.1648 & 0.3614 & 0.4495 & 0.1624 \\
\hline & Free State & 0.2740 & 0.4588 & 0.1257 & 0.2530 & 0.4244 & 0.1073 \\
\hline & KwaZulu-Natal & 0.4103 & 0.4943 & 0.2028 & 0.4316 & 0.4648 & 0.2006 \\
\hline & North West & 0.3818 & 0.4788 & 0.1828 & 0.3923 & 0.4512 & 0.1770 \\
\hline & Gauteng & 0.1239 & 0.4379 & 0.0543 & 0.1479 & 0.4080 & 0.0604 \\
\hline & Mpumalanga & 0.3193 & 0.4592 & 0.1466 & 0.3806 & 0.4403 & 0.1676 \\
\hline & Limpopo & 0.4102 & 0.4588 & 0.1882 & 0.5058 & 0.4441 & 0.2247 \\
\hline \multirow[t]{5}{*}{ Per capita income quintile } & Quintile1 & 0.6913 & 0.4816 & 0.3330 & \multicolumn{3}{|c|}{ Not applicable } \\
\hline & Quintile2 & 0.3701 & 0.4933 & 0.1826 & & & \\
\hline & Quintile3 & 0.2004 & 0.4586 & 0.0919 & & & \\
\hline & Quintile4 & 0.1561 & 0.4432 & 0.0692 & & & \\
\hline & Quintile5 & 0.0384 & 0.4434 & 0.0170 & & & \\
\hline
\end{tabular}

Source: Author's calculations using Census 2011 and Community Survey 2016 data.

Table 4. Topic 10 district councils with the smallest and greatest COVID-19 vulnerability index.

\begin{tabular}{|c|c|c|c|}
\hline \multicolumn{2}{|c|}{2011} & \multicolumn{2}{|c|}{2016} \\
\hline District council & Index & District council & Index \\
\hline \multicolumn{4}{|c|}{ The 10 district councils with the smallest COVID-19 vulnerability index } \\
\hline City of Johannesburg & 0.0427 & Overberg & 0.0466 \\
\hline Ekurhuleni & 0.0517 & Eden (Garden Route) & 0.0522 \\
\hline City of Cape Town & 0.0580 & Sedibeng & 0.0523 \\
\hline Sedibeng & 0.0619 & City of Cape Town & 0.0532 \\
\hline City of Tshwane & 0.0640 & City of Johannesburg & 0.0535 \\
\hline Overberg & 0.0766 & Cape Winelands & 0.0544 \\
\hline Nelson Mandela Bay & 0.0807 & Ekurhuleni & 0.0587 \\
\hline West Rand & 0.0833 & West Coast & 0.0591 \\
\hline eThekwini Metropolitan & 0.0860 & Nelson Mandela Bay & 0.0676 \\
\hline Cape Winelands & 0.0885 & West Rand & 0.0690 \\
\hline \multicolumn{4}{|c|}{ The 10 district councils with the greatest COVID-19 vulnerability index } \\
\hline Alfred Nzo & 0.3896 & Alfred Nzo & 0.4168 \\
\hline Amathole & 0.3852 & OR Tambo & 0.3851 \\
\hline OR Tambo & 0.3758 & Amathole & 0.3355 \\
\hline Harry Gwala & 0.3331 & Umzinyathi & 0.3269 \\
\hline Umzinyathi & 0.3215 & Umkhanyakude & 0.3252 \\
\hline Joe Gqabi & 0.3102 & Zululand & 0.3116 \\
\hline Chris Hani & 0.3073 & Harry Gwala & 0.3083 \\
\hline Ugu & 0.2894 & John Taolo Gaetsewe & 0.2987 \\
\hline Umkhanyakude & 0.2892 & Ugu & 0.2827 \\
\hline Zululand & 0.2849 & Greater Sekhukhune & 0.2805 \\
\hline
\end{tabular}

Source: Author's calculations using Census 2011 and Community Survey 2016 data. 
Table 5. Profile of COVID-19 vulnerable individuals (\%).

\begin{tabular}{|c|c|c|c|c|c|}
\hline & & Not vulnerable & Vulnerable & Not vulnerable & Vulnerable \\
\hline \multirow[t]{3}{*}{ Gender } & Male & 60.17 & 44.72 & 59.53 & 43.22 \\
\hline & Female & 39.83 & 55.28 & 40.47 & 56.78 \\
\hline & & 100.00 & 100.00 & 100.00 & 100.00 \\
\hline \multirow[t]{6}{*}{ Race } & African & 73.59 & 92.72 & 76.26 & 95.11 \\
\hline & Coloured & 10.09 & 5.94 & 10.17 & 4.32 \\
\hline & Indian & 3.42 & 0.44 & 2.95 & 0.24 \\
\hline & White & 12.36 & 0.73 & 10.61 & 0.33 \\
\hline & Unspecified & 0.54 & 0.18 & 0.00 & 0.00 \\
\hline & & 100.00 & 100.00 & 100.00 & 100.00 \\
\hline \multirow[t]{8}{*}{ Age } & $0-14$ years & 0.16 & 0.16 & 0.05 & 0.09 \\
\hline & $15-24$ years & 5.03 & 2.84 & 4.69 & 4.47 \\
\hline & $25-34$ years & 19.40 & 10.27 & 19.26 & 13.09 \\
\hline & $35-44$ years & 26.31 & 15.80 & 26.22 & 16.35 \\
\hline & $45-54$ years & 25.12 & 19.46 & 25.13 & 18.37 \\
\hline & 55-64 years & 14.80 & 22.25 & 15.42 & 21.35 \\
\hline & $65+$ years & 9.19 & 29.22 & 9.23 & 26.27 \\
\hline & & 100.00 & 100.00 & 100.00 & 100.00 \\
\hline \multirow[t]{3}{*}{ Area type } & Urban & 76.35 & 32.58 & 81.05 & 34.08 \\
\hline & Rural & 23.65 & 67.42 & 18.95 & 65.92 \\
\hline & & 100.00 & 100.00 & 100.00 & 100.00 \\
\hline \multirow[t]{10}{*}{ Province } & Western Cape & 13.63 & 5.75 & 14.30 & 4.68 \\
\hline & Eastern Cape & 8.79 & 21.05 & 7.62 & 16.72 \\
\hline & Northern Cape & 2.09 & 2.46 & 2.16 & 2.61 \\
\hline & Free State & 5.82 & 4.88 & 6.03 & 4.36 \\
\hline & KwaZulu-Natal & 16.66 & 25.74 & 15.25 & 24.73 \\
\hline & North West & 6.24 & 8.56 & 6.55 & 9.03 \\
\hline & Gauteng & 29.91 & 9.39 & 33.59 & 12.45 \\
\hline & Mpumalanga & 7.66 & 7.98 & 7.15 & 9.37 \\
\hline & Limpopo & 9.19 & 14.19 & 7.35 & 16.06 \\
\hline & & 100.00 & 100.00 & 100.00 & 100.00 \\
\hline \multirow[t]{6}{*}{ Per capita income quintile } & Quintile1 & 23.42 & 40.24 & \multicolumn{2}{|c|}{ Not applicable } \\
\hline & Quintile2 & 18.29 & 35.80 & & \\
\hline & Quintile3 & 17.60 & 15.05 & & \\
\hline & Quintile4 & 20.61 & 7.13 & & \\
\hline & Quintile5 & 20.09 & 1.78 & & \\
\hline & & 100.00 & 100.00 & & \\
\hline
\end{tabular}

Source: Author's calculations using Census 2011 and Community Survey 2016 data.

thirds share), in Eastern Cape, KwaZulu-Natal or Limpopo, and coming from income quintiles 1 and 2 (75\% share). In contrast, those who were classified as not vulnerable to the pandemic were those coming from households headed by males (60\%), Africans (about three quarters) and relatively younger adults aged 25-54 years (approximately $70 \%$ share), living in urban areas (more than three quarters' share) in Gauteng, Western Cape and KwaZulu-Natal.

It can be seen from Table 6 that in both years, the relative contribution by individuals from African, female- and elderly-headed households was more dominant. The relative contribution of the rural population (about two-thirds) greatly exceeded its population share (around 35\%). Lastly, Eastern Cape, KwaZulu-Natal and Limpopo were the provinces with the largest index contributions; they accounted for about $60 \%$ share of COVID-19 vulnerability, despite only accounting for about $40 \%$ of the population. In addition, the 2011 decomposition results by income quintile indicate that individuals from the two poorest quintiles contributed more than three quarters towards the pandemic vulnerability. 
Table 6. COVID-19 vulnerability index decomposition by demographic, geographical and income characteristics (\%).

\begin{tabular}{|c|c|c|c|c|c|}
\hline & & $\begin{array}{l}\text { Population } \\
\text { share }\end{array}$ & $\begin{array}{c}\text { Contribution } \\
\text { share }\end{array}$ & $\begin{array}{l}\text { Population } \\
\text { share }\end{array}$ & $\begin{array}{c}\text { Contribution } \\
\text { share }\end{array}$ \\
\hline \multirow[t]{3}{*}{ Gender } & Male & 55.37 & 44.22 & 54.33 & 42.45 \\
\hline & Female & 44.63 & 55.78 & 45.67 & 57.55 \\
\hline & & 100.00 & 100.00 & 100.00 & 100.00 \\
\hline \multirow[t]{6}{*}{ Race } & African & 79.53 & 93.26 & 82.27 & 95.52 \\
\hline & Coloured & 8.80 & 5.56 & 8.30 & 3.99 \\
\hline & Indian & 2.50 & 0.38 & 2.09 & 0.21 \\
\hline & White & 8.75 & 0.62 & 7.33 & 0.29 \\
\hline & Unspecified & 0.43 & 0.17 & 0.00 & 0.00 \\
\hline & & 100.00 & 100.00 & 100.00 & 100.00 \\
\hline \multirow[t]{8}{*}{ Age } & $0-14$ years & 0.16 & 0.14 & 0.06 & 0.09 \\
\hline & $15-24$ years & 4.35 & 2.60 & 4.62 & 4.20 \\
\hline & $25-34$ years & 16.56 & 9.52 & 17.29 & 12.23 \\
\hline & $35-44$ years & 23.05 & 14.95 & 23.07 & 15.46 \\
\hline & $45-54$ years & 23.36 & 18.77 & 22.97 & 17.67 \\
\hline & $55-64$ years & 17.11 & 22.75 & 17.31 & 21.82 \\
\hline & $65+$ years & 15.41 & 31.26 & 14.67 & 28.54 \\
\hline & & 100.00 & 100.00 & 100.00 & 100.00 \\
\hline \multirow[t]{3}{*}{ Area type } & Urban & 62.76 & 30.32 & 66.07 & 31.36 \\
\hline & Rural & 37.24 & 69.68 & 33.93 & 68.64 \\
\hline & & 100.00 & 100.00 & 100.00 & 100.00 \\
\hline \multirow[t]{10}{*}{ Province } & Western Cape & 11.18 & 5.26 & 11.23 & 4.21 \\
\hline & Eastern Cape & 12.60 & 22.67 & 10.52 & 17.91 \\
\hline & $\begin{array}{l}\text { Northern } \\
\text { Cape }\end{array}$ & 2.21 & 2.45 & 2.31 & 2.62 \\
\hline & Free State & 5.53 & 4.67 & 5.50 & 4.12 \\
\hline & $\begin{array}{l}\text { KwaZulu- } \\
\text { Natal }\end{array}$ & 19.48 & 26.56 & 18.28 & 25.63 \\
\hline & North West & 6.96 & 8.56 & 7.34 & 9.08 \\
\hline & Gauteng & 23.54 & 8.59 & 26.85 & 11.33 \\
\hline & Mpumalanga & 7.76 & 7.65 & 7.86 & 9.20 \\
\hline & Limpopo & 10.74 & 13.59 & 10.13 & 15.90 \\
\hline & & 100.00 & 100.00 & 100.00 & 100.00 \\
\hline \multirow{6}{*}{$\begin{array}{l}\text { Per capita income } \\
\text { quintile }\end{array}$} & Quintile1 & 28.64 & 40.47 & \multicolumn{2}{|c|}{ Not applicable } \\
\hline & Quintile2 & 23.72 & 36.87 & & \\
\hline & Quintile3 & 16.81 & 14.41 & & \\
\hline & Quintile4 & 16.42 & 6.60 & & \\
\hline & Quintile5 & 14.40 & 1.65 & & \\
\hline & & 100.00 & 100.00 & & \\
\hline
\end{tabular}

Source: Author's calculations using Census 2011 and Community Survey 2016 data.

Moving on to decomposition by indicators, Table 7 shows that in 2011, chronic medication $(12.74 \%)$, car ownership (11.87\%), disability $(11.85 \%)$ and multigenerational households $(11.36 \%)$ were the four indicators contributing most to the vulnerability index. On the other hand, when it comes to CS 2016, the top indicators contributing most to the pandemic vulnerability were car ownership (16.88\%), overcrowding (12.51\%), multigenerational households (11.36\%) and educational attainment $(11.22 \%)$. In addition, Figure 2 shows that the housing and hygiene dimension contributed most to the vulnerability index (2011: 30.56\%: 2016: 36.57\%).

\section{Conclusion}

This study analysed the Census 2011 and CS 2016 data to derive the COVID-19 vulnerability index by revising the original StatsSA 2020 approach. Additional indicators were 
Table 7. COVID-19 vulnerability index decomposition by indicators (\%).

\begin{tabular}{|c|c|c|c|}
\hline Dimension & Indicator & Weight & Contribution \\
\hline \multicolumn{4}{|l|}{2011} \\
\hline \multirow[t]{4}{*}{ Socio-economic } & {$[\mathrm{A}]$ : Education } & 6.25 & 8.56 \\
\hline & [B]: Informal employment & 6.25 & 2.55 \\
\hline & [C]: Car ownership & 6.25 & 11.87 \\
\hline & [D]: Access to media & 6.25 & 0.95 \\
\hline \multirow[t]{2}{*}{ Demographic } & [E]: Multigenerational households & 12.50 & 11.36 \\
\hline & [F]: Overcrowding & 12.50 & 9.55 \\
\hline \multirow[t]{4}{*}{ Housing and hygiene } & [G]: Dwelling type & 6.25 & 5.57 \\
\hline & {$[\mathrm{H}]$ : Refuse removal } & 6.25 & 9.93 \\
\hline & [I]: Water & 6.25 & 5.14 \\
\hline & [J]: Sanitation & 6.25 & 9.91 \\
\hline \multirow[t]{3}{*}{ Health } & [K]: Disability & 12.50 & 11.85 \\
\hline & [L]: Chronic medication & 12.50 & 12.74 \\
\hline & & 100.00 & 100.00 \\
\hline \multicolumn{4}{|l|}{2016} \\
\hline \multirow[t]{3}{*}{ Socio-economic } & [I]: Education & 8.33 & 11.22 \\
\hline & [II]: Car ownership & 8.33 & 16.88 \\
\hline & [III]: Access to media & 8.33 & 0.77 \\
\hline \multirow[t]{2}{*}{ Demographic } & [IV]: Multigenerational households & 12.50 & 11.36 \\
\hline & [V]: Overcrowding & 12.50 & 12.51 \\
\hline \multirow[t]{4}{*}{ Housing and hygiene } & [VI]: Dwelling type & 6.25 & 5.62 \\
\hline & [VII]: Refuse removal & 6.25 & 10.81 \\
\hline & [VIII]: Water & 6.25 & 4.76 \\
\hline & [IX]: Sanitation & 6.25 & 10.04 \\
\hline \multirow[t]{4}{*}{ Health } & [X]: Disability & 8.33 & 5.37 \\
\hline & [XI]: Malnutrition & 8.33 & 5.59 \\
\hline & [XII]: Public healthcare & 8.33 & 5.06 \\
\hline & & 100.00 & 100.00 \\
\hline
\end{tabular}

Source: Author's calculations using Census 2011 and Community Survey 2016 data.

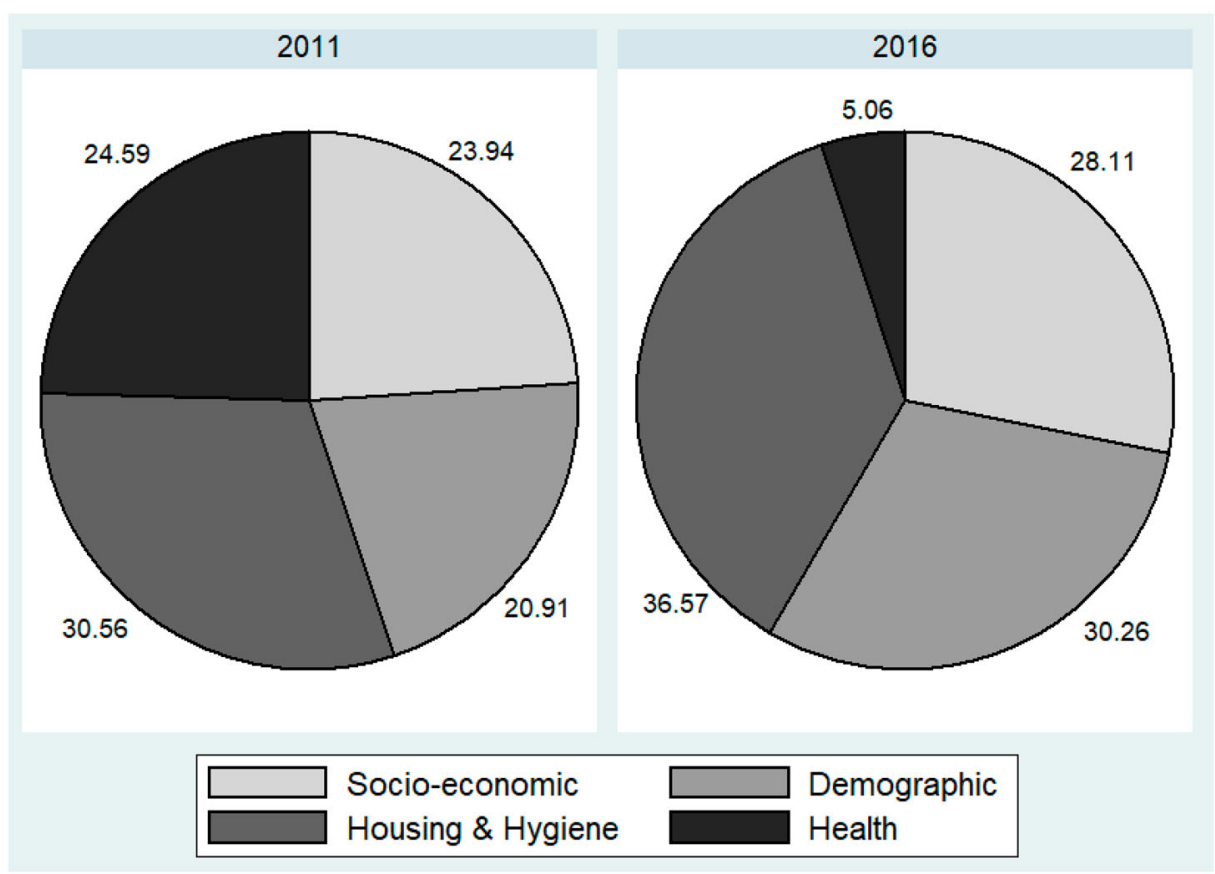

Figure 2. COVID-19 vulnerability index decomposition by dimensions. Source: Authors' calculations using Census 2011 and Community Survey 2016 data. 
included to derive this index, after considering the approach adopted in the recent international studies. The empirical findings of this study indicated that individuals coming from female-, African- and elderly-headed households living in rural areas in Eastern Cape, KwaZulu-Natal and Limpopo provinces were relatively more vulnerable to the pandemic. In addition, residents from the Alfred Nzo, Amathole, Harry Gwala, OR Tambo and Umzinyathi DCs as well as individuals living in numerous municipalities from the Eastern Cape and KwaZulu-Natal provinces were identified as most vulnerable to the pandemic. Furthermore, motor vehicle ownership and multigenerational households were the indicators contributing most to the vulnerability index estimate in both years.

It is hoped that the findings of this study would help prioritise regions and people for resource allocation and adopt risk mitigation strategies to better prepare and response to the COVID-19 pandemic for the remainder of 2021 and even early 2022, before the full South African population would receive the vaccination. Numerous suggestions are raised here. First, for people who do not have their own motor vehicles, the government, in cooperation with the private sector businesses, can consider better promotion of online shopping and delivery of items at their residences by, for example, making certain online shopping websites zero-rated. ${ }^{4}$ Nonetheless, it is important to ensure such initiative will not unfairly knockout small businesses. Hence, there can be additional support to the small firms to help them convert online and even develop a system of home delivery of shopping items.

There can also be greater initiatives on forming a community neighbourhood group to encourage the residents with motor vehicles to have bulk purchases before delivering some of the essential items to fellow neighbours who do not have their own motor vehicles. These initiatives could reduce the likelihood of the less privileged people from going out with public transport and subsequently the probability of exposure to big crowds.

For areas with a high proportion of multigenerational and/or overcrowded households, they can be targeted as hotspot areas with more public tests being conducted, and more hotels can be used as designated quarantine venues for self-isolation purposes (providing the cost is affordable, especially to those coming from the poorer income quintiles), as a way to indirectly help these hotels to operate to close to full capacity. In addition, vulnerable people who need chronic medication should be discouraged from visiting healthcare facilities if possible, but the medication can be delivered directly to their residences (e.g. 3-month supply of medication being delivered to their doors), so as to reduce their chance to go out and possibly get infected with the virus.

Lastly, since the COVID Alert South Africa mobile app has been available from September 2020, there have not been any updates which indicate how effective this app is in contact tracing, if not helping reduce transmission. Hence, it is important for such information to be released before we will know better how to make better use of this app, and whether there is a need to further upgrade some of the features of this app. For example, in Singapore, it is required that everyone who enters places such as shopping malls, schools and banks must first scan the QR codes with their smartphones and input

\footnotetext{
${ }^{4}$ At the time of writing, a total of 1068 websites are zero-rated, as released by Internet Service Providers' Association (2020). However, these websites are almost all related to education and learning.
} 
their personal information, and similarly 'check out' when they leave these places (Nikkei Asia, 2020). On the other hand, Malaysia's contact tracing app not only includes the above-mentioned QR-code scanning feature, but also allows the users to complete a basic survey on travel history, symptoms and recent contact with a confirmed case, before they are automatically classified into different risk categories and informed of the next steps to take (GovInsider, 2020). Hence, the South African governments may consider including these additional features when they plan to upgrade the COVID Alert app in the near future.

\section{Disclosure statement}

No potential conflict of interest was reported by the author(s).

\section{References}

Acharya, R \& Porwal, A, 2020. A vulnerability index for the management of and response to the COVID-19 epidemic in India: an ecological study. Lancet Global Health 8, e1142-e1151.

Alkire, S \& Foster, J, 2011. Understandings and misunderstandings of multidimensional poverty measurement. Journal of Economic Inequality 9(2), 289-314.

Ardington, C, Lam, D, Leibbrandt, M \& Welch, M, 2006. The sensitivity to key data imputations of recent estimates of income poverty and inequality in South Africa. Economic Modelling 23(5), 822-835.

DeCaprio, D, Gartner, J, McCall, CJ, Burgess, T, Garcia, K, Kothari, S \& Sayed, S, 2020. Building a COVID-19 vulnerability index. Journal of Medical Artificial Intelligence 3, 1-10.

Finn, A, Leibbrandt, M \& Woolard, I, 2013. What happened to multidimensional poverty in South Africa between 1993 and 2010? SALDRU Working Papers 99/2012. Southern African Labour and Development Research Unit: University of Cape Town, Rondebosch.

Frame, E, De Lannoy, A \& Leibbrandt, M, 2017. Measuring multidimensional poverty among youth in South Africa at the sub-national level. SALDRU Working Paper Series Number 169. Southern Africa Labour and Development Research Unit, University of Cape Town, Rondebosch.

Fransman, T \& Yu, D, 2019. Multidimensional poverty in South Africa in 2001-16. Development Southern Africa 36(1), 50-79.

GovInsider, 2020. [Online]. Available: Five features of Malaysia's contact tracing tech. https:// govinsider.asia/digital-economy/ministry-of-health-kkm-mahesh-appannan-five-features-ofmalaysias-contact-tracing-tech/ [Accessed 12 January 2021].

Internet Service Providers' Association, 2020. South African zero-rated content (last updated 2020-12-07). [Online]. https://tinyurl.com/zero-rated Accessed 13 January 2021.

Kubheka, T, 2020. Mkhize: COVID-19 Virus Variant Means Young South Africans Also at Risk of Dying. Eyewitness News. [Online]. https://ewn.co.za/2020/12/19/mkhize-covid-19-virusvariant-means-young-south-africans-also-at-risk-of-dying Accessed 13 January 2021.

Lacerda, M, Ardington, C \& Leibbrandt, M, 2008. Sequential regression multiple imputation for incomplete multivariate data using Markov chain Monte Carlo. SALDRU Paper Series Number 13. Southern African Labour and Development Research Unit, University of Cape Town, Rondebosch.

Macharia, PM, Joseph, NK \& Okiro, EA, 2020. A vulnerability index for COVID-19: spatial analysis at the subnational level in Kenya. BMJ Global Health 5, e003014.

Mushongera, D, Zikhail, P \& Ngwenya, P, 2017. A multidimensional poverty index for Gauteng province, South Africa: evidence from Quality of Life Survey data. Social Indicators Research 130(1), 277-303. 
Nair, S, 2020. COVID-19 vulnerability index for the United States counties. Georgia Institute of Technology, Atlanta.

Nikkei Asia, 2020. Singapore mandates use of tracing app as it fights COVID's spread. [Online]. Available: https://asia.nikkei.com/Spotlight/Coronavirus/Singapore-mandates-use-of-tracingapp-as-it-fights-COVID-s-spread [Accessed 12 January 2021].

Omotoso, KO \& Koch, S, 2017. Exploring child poverty and inequality in post-apartheid South Africa: a multidimensional perspective. Working Paper 2017-18. University of Pretoria, Pretoria.

Philip, D \& Rayhan, I, 2004. Vulnerability and poverty: what are the causes and how are they related? Centre for Development Research, University of Bonn, Bonn.

Raghunathan, TE, Lepkowski, JM, Van Hoewyk, J \& Solenberger, P, 2001. A multivariate technique for multiply imputing missing values using a sequence of regression models. Survey Methodology 27(1), 85-95.

Republic of South Africa, 2020. President Cyril Ramaphosa: South Africa's progress in national effort to contain Coronavirus COVID-19 pandemic [Online]. Available: https://www.gov.za/ speeches/president-cyril-ramaphosa-south-africas-response-coronavirus-covid-19-pandemic28-dec-2020 [Accessed 10 January 2021].

Republic of South Africa, 2021. COVID-19 Coronavirus: South African resource portal. [Online]. Available: https://sacoronavirus.co.za/ [Accessed 13 January 2021].

Rogan, M, 2016. Gender and multidimensional poverty in South Africa: applying the global multidimensional poverty index (MPI). Social Indicators Research 126(3), 987-1006.

Santos, ME \& Alkire, S, 2011. Training material for producing national human development reports: the multidimensional poverty Index (MPI). http://www.ophi.org.uk/wp-content/ uploads/MPI_TrainingMaterial_23Nov2011.pdf [Assessed 13 June 2017].

South African Government, 2020. President Cyril Ramaphosa: South Africa's progress in national effort to contain Coronavirus COVID-19 pandemic. [Online]. Available: https://www.gov.za/ speeches/president-cyril-ramaphosa-south-africas-response-coronavirus-covid-19-pandemic28-dec-2020 [Accessed 13 January 2021].

Statistics South Africa, 2014. The South African MPI: creating a multidimensional poverty index using census data. Statistics South Africa, Pretoria.

Statistics South Africa, 2020. South African COVID-19 vulnerability index: technical report. Statistics South Africa, Pretoria.

The Lancet, 2020. Redefining vulnerability in the era of COVID-19. editorial. Lancet 395, 1089.

Vermaak, C, 2008. The impact of multiple imputation of coarsened data on estimates of the working poor in South Africa. Proceedings of the Development Policy Research Unit (DPRU) Conference, 27-29 October, Muldersdrift, South Africa.

Woolard, I \& Leibbrandt, M, 1999. Measuring poverty in South Africa. DPRU Working Paper No. 99/33. Development Policy Research Unit, University of Cape Town, Rondebosch.

World Bank, 2000. World development report 2000/2001: attacking poverty. The World Bank, Washington, DC. 


\section{Appendix}

Table A1. COVID-19 vulnerability index by district councils.

\begin{tabular}{|c|c|c|c|c|c|c|c|c|}
\hline & \multicolumn{4}{|c|}{2011} & \multicolumn{4}{|c|}{2016} \\
\hline & $\mathrm{H}$ & A & Index & Rank & $\mathrm{H}$ & A & Index & Rank \\
\hline Alfred Nzo & 0.7478 & 0.5210 & 0.3896 & 52 & 0.8239 & 0.5058 & 0.4168 & 52 \\
\hline Amajuba & 0.3658 & 0.4826 & 0.1766 & 32 & 0.4140 & 0.4470 & 0.1851 & 31 \\
\hline Amathole & 0.7115 & 0.5414 & 0.3852 & 51 & 0.6918 & 0.4849 & 0.3355 & 50 \\
\hline Bojanala & 0.3346 & 0.4592 & 0.1536 & 27 & 0.3632 & 0.4351 & 0.1580 & 28 \\
\hline Buffalo City & 0.2757 & 0.4808 & 0.1326 & 20 & 0.2971 & 0.4438 & 0.1319 & 22 \\
\hline Cape Winelands & 0.1993 & 0.4443 & 0.0885 & 10 & 0.1364 & 0.3988 & 0.0544 & 6 \\
\hline Capricorn & 0.3700 & 0.4567 & 0.1690 & 31 & 0.4429 & 0.4419 & 0.1957 & 32 \\
\hline Central Karoo & 0.2289 & 0.4351 & 0.0996 & 14 & 0.1831 & 0.4032 & 0.0738 & 12 \\
\hline Chris Hani & 0.5850 & 0.5253 & 0.3073 & 46 & 0.5805 & 0.4706 & 0.2732 & 42 \\
\hline City of Cape Town & 0.1343 & 0.4319 & 0.0580 & 3 & 0.1318 & 0.4034 & 0.0532 & 4 \\
\hline City of Johannesburg & 0.0988 & 0.4316 & 0.0427 & 1 & 0.1332 & 0.4014 & 0.0535 & 5 \\
\hline City of Tshwane & 0.1443 & 0.4434 & 0.0640 & 5 & 0.1742 & 0.4195 & 0.0731 & 11 \\
\hline Dr Kenneth Kaunda & 0.2401 & 0.4637 & 0.1113 & 16 & 0.2165 & 0.4272 & 0.0925 & 18 \\
\hline Dr Ruth Segomotsi Mompati & 0.5187 & 0.4950 & 0.2568 & 40 & 0.5504 & 0.4735 & 0.2606 & 40 \\
\hline Eden (Garden Route) & 0.2168 & 0.4522 & 0.0980 & 12 & 0.1276 & 0.4094 & 0.0522 & 2 \\
\hline Ehlanzeni & 0.3493 & 0.4536 & 0.1584 & 28 & 0.4506 & 0.4373 & 0.1971 & 33 \\
\hline Ekurhuleni & 0.1190 & 0.4349 & 0.0517 & 2 & 0.1458 & 0.4028 & 0.0587 & 7 \\
\hline eThekwini & 0.1887 & 0.4557 & 0.0860 & 9 & 0.1992 & 0.4234 & 0.0844 & 15 \\
\hline Fezile Dabi & 0.2135 & 0.4448 & 0.0950 & 11 & 0.1927 & 0.4121 & 0.0794 & 13 \\
\hline Frances Baard & 0.2639 & 0.4654 & 0.1228 & 18 & 0.2912 & 0.4217 & 0.1228 & 21 \\
\hline Gert Sibande & 0.3061 & 0.4742 & 0.1452 & 24 & 0.3278 & 0.4506 & 0.1477 & 26 \\
\hline Harry Gwala & 0.6523 & 0.5106 & 0.3331 & 49 & 0.6377 & 0.4834 & 0.3083 & 46 \\
\hline iLembe & 0.5059 & 0.4990 & 0.2525 & 38 & 0.5125 & 0.4738 & 0.2428 & 38 \\
\hline Joe Gqabi & 0.6068 & 0.5112 & 0.3102 & 47 & 0.5232 & 0.4623 & 0.2419 & 36 \\
\hline John Taolo Gaetsewe & 0.5087 & 0.4962 & 0.2524 & 37 & 0.6096 & 0.4900 & 0.2987 & 45 \\
\hline King Cetshwayo & 0.5211 & 0.5119 & 0.2668 & 42 & 0.5170 & 0.4805 & 0.2484 & 39 \\
\hline Lejweleputswa & 0.2545 & 0.4593 & 0.1169 & 17 & 0.2469 & 0.4241 & 0.1047 & 20 \\
\hline Mangaung & 0.2416 & 0.4539 & 0.1097 & 15 & 0.2046 & 0.4175 & 0.0854 & 16 \\
\hline Mopani & 0.4184 & 0.4585 & 0.1919 & 35 & 0.5319 & 0.4419 & 0.2350 & 35 \\
\hline Namakwa & 0.2993 & 0.4550 & 0.1362 & 22 & 0.1932 & 0.4118 & 0.0796 & 14 \\
\hline Nelson Mandela Bay & 0.1809 & 0.4461 & 0.0807 & 7 & 0.1641 & 0.4119 & 0.0676 & 9 \\
\hline Ngaka Modiri Molema & 0.5073 & 0.4985 & 0.2529 & 39 & 0.5163 & 0.4695 & 0.2424 & 37 \\
\hline Nkangala & 0.2899 & 0.4559 & 0.1322 & 19 & 0.3365 & 0.4371 & 0.1471 & 25 \\
\hline OR Tambo & 0.7181 & 0.5233 & 0.3758 & 50 & 0.7721 & 0.4988 & 0.3851 & 51 \\
\hline Overberg & 0.1736 & 0.4413 & 0.0766 & 6 & 0.1156 & 0.4034 & 0.0466 & 1 \\
\hline Pixley ka Seme & 0.3178 & 0.4730 & 0.1503 & 25 & 0.3211 & 0.4331 & 0.1391 & 24 \\
\hline Sarah Baartman & 0.2922 & 0.4556 & 0.1332 & 21 & 0.2266 & 0.4225 & 0.0957 & 19 \\
\hline Sedibeng & 0.1412 & 0.4380 & 0.0619 & 4 & 0.1289 & 0.4056 & 0.0523 & 3 \\
\hline Sekhukhune & 0.4852 & 0.4629 & 0.2246 & 36 & 0.6153 & 0.4558 & 0.2805 & 43 \\
\hline Thabo Mofutsanyane & 0.3538 & 0.4679 & 0.1655 & 29 & 0.3537 & 0.4345 & 0.1537 & 27 \\
\hline Ugu & 0.5663 & 0.5111 & 0.2894 & 45 & 0.5996 & 0.4715 & 0.2827 & 44 \\
\hline uMgungundlovu & 0.3834 & 0.4828 & 0.1851 & 33 & 0.3671 & 0.4412 & 0.1620 & 29 \\
\hline uMkhanyakude & 0.5826 & 0.4964 & 0.2892 & 44 & 0.6868 & 0.4736 & 0.3252 & 48 \\
\hline uMzinyathi & 0.6325 & 0.5083 & 0.3215 & 48 & 0.6831 & 0.4786 & 0.3269 & 49 \\
\hline Uthukela & 0.5255 & 0.4982 & 0.2618 & 41 & 0.5709 & 0.4716 & 0.2692 & 41 \\
\hline Vhembe & 0.4152 & 0.4567 & 0.1897 & 34 & 0.5080 & 0.4366 & 0.2218 & 34 \\
\hline Waterberg & 0.3344 & 0.4588 & 0.1534 & 26 & 0.3983 & 0.4439 & 0.1768 & 30 \\
\hline West Coast & 0.2237 & 0.4440 & 0.0994 & 13 & 0.1457 & 0.4056 & 0.0591 & 8 \\
\hline West Rand & 0.1862 & 0.4475 & 0.0833 & 8 & 0.1668 & 0.4136 & 0.0690 & 10 \\
\hline Xhariep & 0.3124 & 0.4542 & 0.1419 & 23 & 0.2223 & 0.4120 & 0.0916 & 17 \\
\hline ZF Mgcawu & 0.3557 & 0.4719 & 0.1678 & 30 & 0.3110 & 0.4281 & 0.1331 & 23 \\
\hline Zululand & 0.5683 & 0.5013 & 0.2849 & 43 & 0.6386 & 0.4879 & 0.3116 & 47 \\
\hline
\end{tabular}

Source: Author's calculations using Census 2011 and Community Survey 2016 data. 
Table A2. COVID-19 vulnerability index in 2011 by district councils at different thresholds.

\begin{tabular}{|c|c|c|c|c|c|c|c|c|}
\hline & \multicolumn{2}{|c|}{ Threshold: 0.25} & \multicolumn{2}{|c|}{ Threshold: 0.33} & \multicolumn{2}{|c|}{ Threshold: 0.40} & \multicolumn{2}{|c|}{ Threshold: 0.50} \\
\hline & Index & Rank & Index & Rank & Index & Rank & Index & Rank \\
\hline Alfred Nzo & 0.4452 & 52 & 0.3896 & 52 & 0.3304 & 51 & 0.2686 & 51 \\
\hline Amajuba & 0.2481 & 30 & 0.1766 & 32 & 0.1367 & 34 & 0.0970 & 34 \\
\hline Amathole & 0.4353 & 51 & 0.3852 & 51 & 0.3391 & 52 & 0.2852 & 52 \\
\hline Bojanala & 0.2364 & 27 & 0.1536 & 27 & 0.1068 & 24 & 0.0694 & 24 \\
\hline Buffalo City & 0.1973 & 19 & 0.1326 & 20 & 0.1001 & 23 & 0.0703 & 25 \\
\hline Cape Winelands & 0.1667 & 10 & 0.0885 & 10 & 0.0559 & 9 & 0.0333 & 9 \\
\hline Capricorn & 0.2603 & 33 & 0.1690 & 31 & 0.1169 & 29 & 0.0767 & 29 \\
\hline Central Karoo & 0.1840 & 16 & 0.0996 & 14 & 0.0583 & 10 & 0.0336 & 10 \\
\hline Chris Hani & 0.3660 & 45 & 0.3073 & 46 & 0.2616 & 47 & 0.2145 & 48 \\
\hline City of Cape Town & 0.1214 & 3 & 0.0580 & 3 & 0.0334 & 3 & 0.0178 & 3 \\
\hline City of Johannesburg & 0.0983 & 1 & 0.0427 & 1 & 0.0252 & 1 & 0.0127 & 1 \\
\hline City of Tshwane & 0.1223 & 4 & 0.0640 & 5 & 0.0403 & 5 & 0.0235 & 5 \\
\hline Dr Kenneth Kaunda & 0.1832 & 15 & 0.1113 & 16 & 0.0780 & 16 & 0.0502 & 16 \\
\hline Dr Ruth Segomotsi Mompati & 0.3334 & 42 & 0.2568 & 40 & 0.2065 & 40 & 0.1565 & 40 \\
\hline Eden (Garden Route) & 0.1693 & 11 & 0.0980 & 12 & 0.0652 & 14 & 0.0415 & 14 \\
\hline Ehlanzeni & 0.2575 & 32 & 0.1584 & 28 & 0.1084 & 27 & 0.0668 & 23 \\
\hline Ekurhuleni & 0.1096 & 2 & 0.0517 & 2 & 0.0306 & 2 & 0.0168 & 2 \\
\hline eThekwini & 0.1523 & 9 & 0.0860 & 9 & 0.0586 & 11 & 0.0366 & 12 \\
\hline Fezile Dabi & 0.1703 & 12 & 0.0950 & 11 & 0.0609 & 12 & 0.0359 & 11 \\
\hline Frances Baard & 0.1958 & 18 & 0.1228 & 18 & 0.0879 & 18 & 0.0581 & 19 \\
\hline Gert Sibande & 0.2150 & 22 & 0.1452 & 24 & 0.1076 & 26 & 0.0759 & 28 \\
\hline Harry Gwala & 0.3935 & 49 & 0.3331 & 49 & 0.2766 & 49 & 0.2197 & 49 \\
\hline iLembe & 0.3253 & 39 & 0.2525 & 38 & 0.2042 & 37 & 0.1554 & 39 \\
\hline Joe Gqabi & 0.3727 & 47 & 0.3102 & 47 & 0.2568 & 46 & 0.2045 & 46 \\
\hline John Taolo Gaetsewe & 0.3248 & 37 & 0.2524 & 37 & 0.2048 & 38 & 0.1519 & 37 \\
\hline King Cetshwayo & 0.3303 & 40 & 0.2668 & 42 & 0.2223 & 42 & 0.1748 & 42 \\
\hline Lejweleputswa & 0.1916 & 17 & 0.1169 & 17 & 0.0805 & 17 & 0.0526 & 17 \\
\hline Mangaung & 0.1815 & 14 & 0.1097 & 15 & 0.0751 & 15 & 0.0461 & 15 \\
\hline Mopani & 0.2920 & 35 & 0.1919 & 35 & 0.1347 & 33 & 0.0860 & 33 \\
\hline Namakwa & 0.2177 & 23 & 0.1362 & 22 & 0.0955 & 21 & 0.0580 & 18 \\
\hline Nelson Mandela Bay & 0.1442 & 6 & 0.0807 & 7 & 0.0519 & 7 & 0.0307 & 7 \\
\hline Ngaka Modiri Molema & 0.3251 & 38 & 0.2529 & 39 & 0.2059 & 39 & 0.1545 & 38 \\
\hline Nkangala & 0.2121 & 21 & 0.1322 & 19 & 0.0909 & 19 & 0.0583 & 22 \\
\hline OR Tambo & 0.4298 & 50 & 0.3758 & 50 & 0.3195 & 50 & 0.2639 & 50 \\
\hline Overberg & 0.1491 & 8 & 0.0766 & 6 & 0.0466 & 6 & 0.0287 & 6 \\
\hline Pixley ka Seme & 0.2330 & 25 & 0.1503 & 25 & 0.1110 & 28 & 0.0752 & 27 \\
\hline Sarah Baartman & 0.2101 & 20 & 0.1332 & 21 & 0.0915 & 20 & 0.0581 & 20 \\
\hline Sedibeng & 0.1260 & 5 & 0.0619 & 4 & 0.0368 & 4 & 0.0215 & 4 \\
\hline Sekhukhune & 0.3237 & 36 & 0.2246 & 36 & 0.1623 & 36 & 0.1061 & 36 \\
\hline Thabo Mofutsanyane & 0.2471 & 29 & 0.1655 & 29 & 0.1212 & 30 & 0.0824 & 30 \\
\hline Ugu & 0.3569 & 44 & 0.2894 & 45 & 0.2397 & 45 & 0.1897 & 45 \\
\hline uMgungundlovu & 0.2560 & 31 & 0.1851 & 33 & 0.1434 & 35 & 0.1017 & 35 \\
\hline uMkhanyakude & 0.3674 & 46 & 0.2892 & 44 & 0.2318 & 43 & 0.1769 & 43 \\
\hline uMzinyathi & 0.3842 & 48 & 0.3215 & 48 & 0.2676 & 48 & 0.2084 & 47 \\
\hline Uthukela & 0.3310 & 41 & 0.2618 & 41 & 0.2135 & 41 & 0.1606 & 41 \\
\hline Vhembe & 0.2917 & 34 & 0.1897 & 34 & 0.1321 & 32 & 0.0836 & 31 \\
\hline Waterberg & 0.2351 & 26 & 0.1534 & 26 & 0.1069 & 25 & 0.0706 & 26 \\
\hline West Coast & 0.1724 & 13 & 0.0994 & 13 & 0.0627 & 13 & 0.0381 & 13 \\
\hline West Rand & 0.1462 & 7 & 0.0833 & 8 & 0.0542 & 8 & 0.0317 & 8 \\
\hline Xhariep & 0.2250 & 24 & 0.1419 & 23 & 0.0979 & 22 & 0.0582 & 21 \\
\hline ZF Mgcawu & 0.2399 & 28 & 0.1678 & 30 & 0.1226 & 31 & 0.0845 & 32 \\
\hline Zululand & 0.3535 & 43 & 0.2849 & 43 & 0.2342 & 44 & 0.1795 & 44 \\
\hline
\end{tabular}

Source: Author's calculations using Census 2011 and Community Survey 2016 data. 
Table A3. The 30 municipalities with the greatest COVID-19 vulnerability index.

\begin{tabular}{|c|c|c|c|c|c|}
\hline Municipality & Province & Index & Municipality & Province & Index \\
\hline Mbhashe & Eastern Cape & 0.4742 & Mbizana & Eastern Cape & 0.4755 \\
\hline Intsika Yethu & Eastern Cape & 0.4606 & Ntabankulu & Eastern Cape & 0.4568 \\
\hline Mbizana & Eastern Cape & 0.4384 & Ngquza Hill & Eastern Cape & 0.4403 \\
\hline Engcobo & Eastern Cape & 0.4372 & Ratlou & North West & 0.4362 \\
\hline Ntabankulu & Eastern Cape & 0.4213 & Nkandla & KwaZulu-Natal & 0.4346 \\
\hline Nyandeni & Eastern Cape & 0.4188 & Port St Johns & Eastern Cape & 0.4297 \\
\hline Ingwe & KwaZulu-Natal & 0.4114 & Joe Morolong & Northern Cape & 0.4253 \\
\hline Umzumbe & KwaZulu-Natal & 0.4086 & Mbhashe & Eastern Cape & 0.4220 \\
\hline Mnquma & Eastern Cape & 0.3976 & Engcobo & Eastern Cape & 0.4166 \\
\hline Port St Johns & Eastern Cape & 0.3974 & Msinga & KwaZulu-Natal & 0.4155 \\
\hline Ngquza Hill & Eastern Cape & 0.3905 & Intsika Yethu & Eastern Cape & 0.4071 \\
\hline Ntambanana & KwaZulu-Natal & 0.3900 & Nyandeni & Eastern Cape & 0.4071 \\
\hline Ezingoleni & KwaZulu-Natal & 0.3896 & Nongoma & KwaZulu-Natal & 0.4038 \\
\hline Msinga & KwaZulu-Natal & 0.3886 & Mhlontlo & Eastern Cape & 0.3960 \\
\hline Elundini & Eastern Cape & 0.3874 & Umzumbe & KwaZulu-Natal & 0.3947 \\
\hline Mhlontlo & Eastern Cape & 0.3839 & Ubuhlebezwe & KwaZulu-Natal & 0.3846 \\
\hline Vulamehlo & KwaZulu-Natal & 0.3809 & Ndwedwe & KwaZulu-Natal & 0.3808 \\
\hline Nkandla & KwaZulu-Natal & 0.3718 & Maphumulo & KwaZulu-Natal & 0.3800 \\
\hline Ubuhlebezwe & KwaZulu-Natal & 0.3692 & Umzimvubu & Eastern Cape & 0.3721 \\
\hline Maphumulo & KwaZulu-Natal & 0.3637 & Emalahleni & Eastern Cape & 0.3583 \\
\hline Umlalazi & KwaZulu-Natal & 0.3615 & Dr Nkosazana Dlamini Zuma & KwaZulu-Natal & 0.3578 \\
\hline Mkhambathini & KwaZulu-Natal & 0.3583 & Mnquma & Eastern Cape & 0.3563 \\
\hline Amahlathi & Eastern Cape & 0.3533 & Greater Taung & North West & 0.3507 \\
\hline Umzimkhulu & KwaZulu-Natal & 0.3521 & Emadlangeni & KwaZulu-Natal & 0.3492 \\
\hline Joe Morolong & Northern Cape & 0.3501 & Matatiele & Eastern Cape & 0.3485 \\
\hline Matatiele & Eastern Cape & 0.3494 & Big Five Hlabisa & KwaZulu-Natal & 0.3450 \\
\hline Nongoma & KwaZulu-Natal & 0.3489 & Umzimkhulu & KwaZulu-Natal & 0.3419 \\
\hline Umzimvubu & Eastern Cape & 0.3472 & Nqutu & KwaZulu-Natal & 0.3417 \\
\hline Ratlou & North West & 0.3451 & Umuziwabantu & KwaZulu-Natal & 0.3387 \\
\hline Ngqushwa & Eastern Cape & 0.3448 & Kagisano/Molopo & North West & 0.3384 \\
\hline
\end{tabular}

Source: Author's calculations using Census 2011 and Community Survey 2016 data. 